\title{
Molecular detection of Leishmania infantum and Leishmania tropica in rodent species from endemic cutaneous leishmaniasis areas in Morocco
}

Mohamed Echchakery ${ }^{1 *}$, Carmen Chicharro², Samia Boussaa ${ }^{1,3}$, Javier Nieto ${ }^{2}$ Eugenia Carrillo², Ortega Sheila ${ }^{2}$, Javier Moreno ${ }^{2}$ and Ali Boumezzough ${ }^{1}$

\begin{abstract}
Background: Leishmaniasis remains a major public health problem in African nations, including Morocco, where little is known about the vertebrate reservoirs involved in the causal parasites' transmission cycles. The present study investigates the role of rodent species as potential reservoirs of Leishmania spp. in central Morocco, where both $L$. tropica and $L$. infantum have been reported.

Methods: Rodents were caught from 22 sites in central Morocco, by using Sherman metal traps, and identified morphologically. For each specimen, genomic DNA was extracted from different tissues using the Speed Tools DNA extraction Kit. Then, samples were PCR-analyzed, targeting the SSU rRNA gene to detect Leishmania spp. DNA, followed by amplification of the internal transcribed spacer 1 (ITS1) and its sequencing to identify the species.

Results: A total of 197 rodents belonging to ten species were captured and identified: Rattus rattus (40.61\%), Mus musculus (25.38\%), Apodemus sylvaticus (8.63\%), Mus spretus (7.11\%), Meriones shawi (5.58\%), Rattus norvegicus (4.57\%), Meriones libycus (3.05\%), Mastomys erythroleucus (2.03\%), Gerbillus campestris (2.03\%) and Lemniscomys barbarus (1.01\%). Molecular analysis revealed the presence of Leishmania species in 18 specimens: six $R$. rattus (out of 80 captured; 7.5\%), 11 M. musculus (out of 50 captured; 22\%), and one R. norvegicus (out of 9 captured; 11.11\%).

Conclusions: To the best of our knowledge, L. infantum and L. tropica were identified in rodent species for the first time in Morocco. These findings suggest that rodent species may be involved in L. infantum and L. tropica transmission cycles in this country but that further studies are needed to confirm their role as reservoirs of Leishmania species in Morocco.
\end{abstract}

Keywords: Leishmania tropica, L. infantum, LnPCR, ITS1 PCR, Rodents, Morocco

\section{Background}

Leishmaniasis is a vector-borne infectious disease caused by members of the genus Leishmania (Kinetoplastida: Trypanosomatidae) and transmitted by phlebotomine sand flies (Diptera: Psychodidae) [1]. In the Mediterranean basin, the primary reservoir hosts of Leishmania spp. are wild mammals, mainly rodents and canids [2-5].

\footnotetext{
* Correspondence: mohamedechchakery@gmail.com

${ }^{1}$ Ecology and the Environment Laboratory L2E, (URAC 32, CNRST ERACNERS 06), Faculty of Sciences Semlalia, Cadi Ayyad University, Marrakesh, Morocco

Full list of author information is available at the end of the article
}

Leishmaniasis remains one of the major public health problems in Morocco where three Leishmania species coexist [6]. Leishmania infantum causes mainly zoonotic visceral leishmaniasis; $L$. major causes zoonotic cutaneous leishmaniasis and L. tropica causes anthroponotic cutaneous leishmaniasis [6]. Certainly, natural Leishmania infections have been reported in many rodent species, such as Mus musculus, Rattus norvegicus, Rattus rattus and Apodemus sylvaticus [7-17]. However, in Morocco, the only proven rodent reservoir of Leishmania (L. major MON 25) is Meriones shawi (Rodentia: 
Gerbillidae) [18, 19], despite the country being rich in rodent species [20].

The detection of infection in wild and domestic animals is the first step in identifying the different host reservoirs of Leishmania spp. Host incrimination depends on the accumulation of evidence based on five criteria [21, 22]: (i) geographical and temporal overlapping of vectors and hosts distributions; (ii) survival of the reservoir host long enough to permit transmission; (iii) higher infection prevalence; (iv) presence and frequency of parasites in the skin or the blood to be infective for the vector; and (v) detection of the same Leishmania species in human cases and the reservoir host.

In the present work, molecular methods were used to detect Leishmania infection in wild-caught rodents from central Morocco, from where both cutaneous and visceral leishmaniasis has been reported in humans [17, 23].

\section{Methods}

\section{Study area}

This study was conducted in four regions of central Morocco: Al Haouz, Chichaoua, Essaouira and Marrakesh. A total of 22 sites (Fig. 1) with altitudes between 318 and $2579 \mathrm{~m}$ were sampled. Across the study area, the climate is arid to semi-arid on the plain (up to $450 \mathrm{~m}$ in Marrakesh) and humid in the Atlas Mountains (right up to $4167 \mathrm{~m}$ on Toubkal Mountain) and on the coast (up to $50 \mathrm{~m}$ in Essaouira).

\section{Rodent collection}

The presence of rodents was surmised from cut plant stems and fresh droppings. Animals were captured using metal Sherman baited traps placed at the entrances of active burrows. For catching many rodent species, different baits were used in the same trap: bread with olive oil, tomatoes, potatoes and dates. The traps were set in the afternoon and recovered early the next morning. Forty traps were placed twice monthly (every 15 days) at each site between June 2014 and May 2015.

\section{Treatment of captured rodents and DNA extraction}

In the laboratory, caught rodents were anaesthetized with ether for the purposes of species identification and collecting data on weight, length (body and tail) and skin lesions (according to European decree NOR: AGRG1238767A 2013). Species identifications were made according to morphological characteristics [24]. Samples of liver, spleen, bone marrow and skin (ear lobe and, when available, skin lesions) (Fig. 2) were then harvested for parasite detection.25-30 mg of each tissue was removed with the aid of single-use forceps, scissors and scalpel blades, placed in sterile tubes, and stored at $-20{ }^{\circ} \mathrm{C}$ for DNA extraction.
Genomic DNA was extracted using the Speed Tools DNA extraction Kit (Biotools, Madrid, Spain) following the manufacturer's recommendations, and was eluted in a final volume of $200 \mu \mathrm{l}$ of PCR-grade water. The extracts were stored at $4{ }^{\circ} \mathrm{C}$ until PCR analysis.

\section{Detection of Leishmania spp. DNA}

The extracted DNA was screened for Leishmania spp. by the LnPCR amplifying a fragment from the small subunit ribosomal ribonucleic acid gene SSU rRNA [25, 26]. The first amplification step (Table 1) was performed using R221 (specific for order Kinetoplastida) and R332 primers (specific for the genera Leishmania and Crithidia) [25]. The PCR product was then tested in a subsequent amplification step with R233 and R333 primers of the genus Leishmania, according to the protocol developed by Van Eys et al. [25] and adapted and modified by Cruz et al. [27].

A reamplification reaction was then performed in a $25 \mu \mathrm{l}$ final volume, involving $10 \mu \mathrm{l}$ of a $1 / 40$ dilution of the first PCR amplicons as a template was added to a PCR mixture (Table 1). The components, total reaction volume and programs for the implementation of the LnPCR are detailed in Table 1. The amplification products were resolved on a $1.5 \%$ agarose gel, stained with Gel Red Nucleic Acid stain (Biotium, Fremont, California, USA), and visualized under UV light. Samples yielding a PCR product of 603 bp (Additional file 1: Figure S1) and 358 bp (Additional file 1: Figure S2), respectively, by first and second amplification reaction were deemed positive for Leishmania spp. DNA.

Negative controls without DNA were employed in all assays. DNA from the reference Leishmania infantum strain MHOM/FR/78/LEM75 was used as a positive control (Additional file 1: Figures S1-S3).

\section{Identification of Leishmania species}

Samples shown to be positive by LnPCR were further analyzed to identify the Leishmania species by nested amplification of the ribosomal internal transcribed spacer 1 (ITS1-PCR).

The first PCR reaction was carried out using the primers LITSR/L5.8S as described by El Tai et al. [28] and Schönian et al. [29]. Amplification reactions were performed in volumes of $50 \mu \mathrm{l}$ was added to a PCR mixture described in Table 1 . For the second reaction, we used the primers SAC and VAN2 [30]. A reamplification reaction was then performed in a $25 \mu \mathrm{l}$ final volume, involving $10 \mu \mathrm{l}$ of a $1 / 40$ dilution of the first PCR amplicons as a template was added to a PCR mixture described in Table 1.

Negative and positive controls were also included in this assay. All reactive were synthesized commercially (Biotools, B\&M Labs, S.A., Madrid, Spain). All PCR 


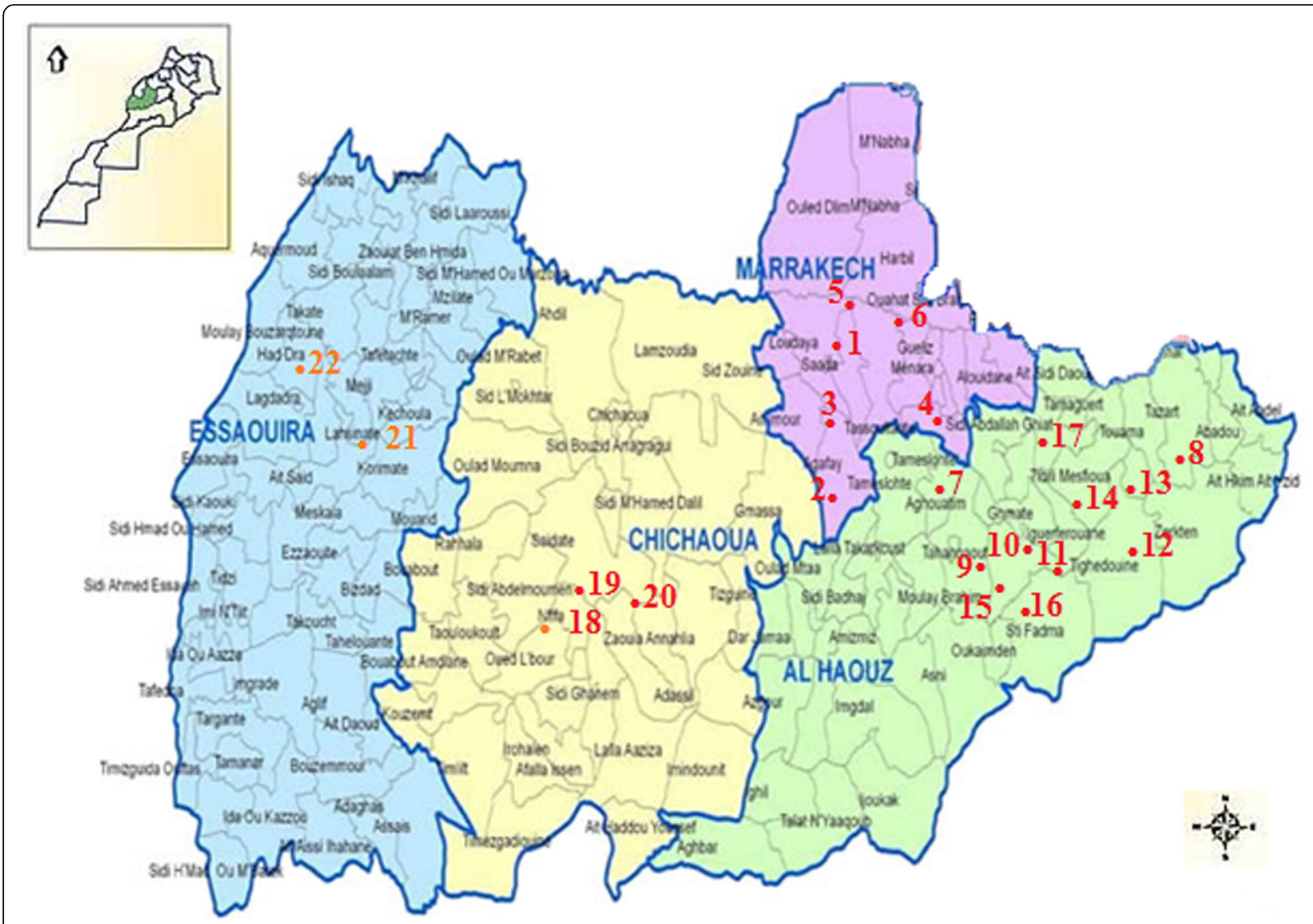

Fig. 1 Local map showing the study area. Numbers (1-22) indicate sampling sites

products were visualized on $1.5 \%$ agarose gel as above (Additional file 1: Figure S3). Samples providing a 300350 bp (Additional file 1: Figure S2) and 280-330 bp (Additional file 1: Figure S3), respectively, were deemed positive. The ITS1-PCR products were excised from the agarose gels and purified using the QIA quick extraction kit (Qiagen). They were then sequenced which allows to correctly identify all species of the genus Leishmania of the Old World [31], using the Big-Dye Terminator Cycle Sequencing Ready Reaction kit v3.1 and an automated
ABI PRISM 377 DNA sequencer (Applied Biosystems, Foster City, CA, USA). These sequences were edited using BioEdit Sequence Alignment Editor Software v. 7.0.9.0 [32] and compared with others held in the GenBank database using BLAST software.

\section{Results}

A total of 197 animals belonging to 10 rodent species were captured (Table 2): 80 Rattus rattus (40.61\%), 50 Mus musculus (25.38\%), 17 Apodemus sylvaticus (8.63\%), 14

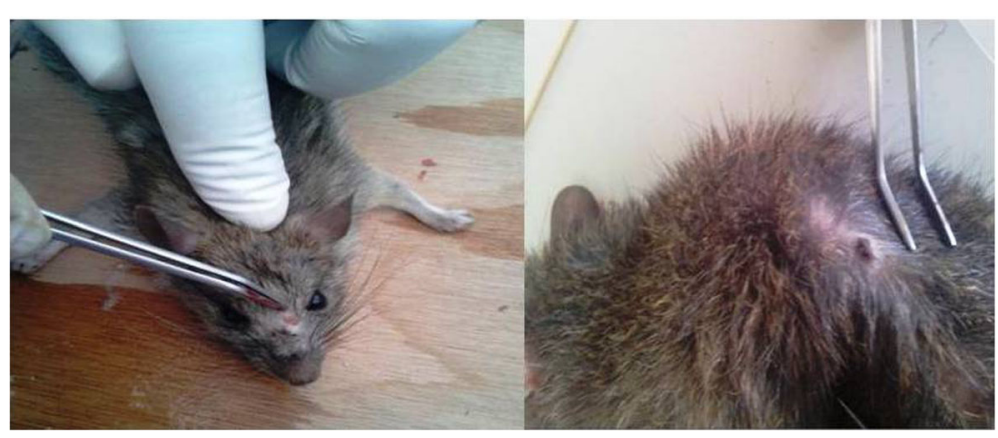

Fig. 2 Skin lesions in rodent specimens 
Table 1 PCR methods and primers sequences and main conditions used in this study

\begin{tabular}{|c|c|c|c|c|c|c|c|c|c|c|c|}
\hline Gene & Primer & $\begin{array}{l}\text { Product } \\
\text { size (bp) }\end{array}$ & Primer sequence $\left(5^{\prime}-3^{\prime}\right)$ & $\begin{array}{l}\text { Amplification } \\
\text { conditions }\end{array}$ & $\begin{array}{l}\mathrm{H}_{2} \mathrm{O} \\
(\mu \mathrm{l})^{\mathrm{a}}\end{array}$ & $\begin{array}{l}\mathrm{MgCl}_{2} \\
(\mu \mathrm{l})\end{array}$ & $\begin{array}{l}\text { dNTP } \\
(0.2 \mathrm{mM}) \\
(\mu \mathrm{l})\end{array}$ & Primer $(\mu l)$ & $\begin{array}{l}\text { Units Taq DNA } \\
\text { polymerase }(\mu \mathrm{l})\end{array}$ & $\begin{array}{l}\text { DNA } \\
(\mu \mathrm{l})\end{array}$ & $\begin{array}{l}\text { Total } \\
\text { volume } \\
(\mu l)\end{array}$ \\
\hline \multirow[t]{4}{*}{ SSU } & R221 & \multirow[t]{2}{*}{603} & GGTTCCTITCCTGATTTACG & \multirow{2}{*}{$\begin{array}{l}94{ }^{\circ} \mathrm{C} \text { for } \\
5 \mathrm{~min}, 94{ }^{\circ} \mathrm{C} \\
\text { for } 30 \mathrm{~s}, 60^{\circ} \mathrm{C} \\
\text { for } 30 \mathrm{~s}, 72{ }^{\circ} \mathrm{C} \\
\text { for } 30 \mathrm{~s}, 72^{\circ} \mathrm{C} \\
\text { for } 5 \mathrm{~min} \\
\text { (30 cycles) }\end{array}$} & \multirow[t]{2}{*}{30.6} & \multirow[t]{2}{*}{5.0} & \multirow[t]{2}{*}{1.0} & \multirow[t]{2}{*}{1.0 (15 pmol) } & \multirow[t]{2}{*}{$1.4(1 \mathrm{U} / \mu \mathrm{l})$} & \multirow[t]{2}{*}{10} & \multirow[t]{2}{*}{50} \\
\hline & R332 & & GGCCGGTAAAGGCCGAATAG & & & & & & & & \\
\hline & R223 & \multirow[t]{2}{*}{358} & TCCCATCGCAACCTCGGTT & \multirow{2}{*}{$\begin{array}{l}94{ }^{\circ} \mathrm{C} \text { for } \\
5 \mathrm{~min}, 94^{\circ} \mathrm{C} \\
\text { for } 30 \mathrm{~s}, 65^{\circ} \mathrm{C} \\
\text { for } 30 \mathrm{~s}, 72^{\circ} \mathrm{C} \\
\text { for } 30 \mathrm{~s}, 72^{\circ} \mathrm{C} \\
\text { for } 5 \mathrm{~min} \\
\text { (30 cycles) }\end{array}$} & \multirow[t]{2}{*}{10.6} & \multirow[t]{2}{*}{2.5} & \multirow[t]{2}{*}{0.5} & 0.5 (7.5 pmol) & \multirow[t]{2}{*}{$0.7(0.5 \mathrm{U} / \mu \mathrm{l})$} & \multirow[t]{2}{*}{$10^{\mathrm{a}}$} & \multirow[t]{2}{*}{25} \\
\hline & R333 & & AAAGCGGGCGCGGTGCTG & & & & & $0.25(3.75 \mathrm{pmol})$ & & & \\
\hline \multirow[t]{4}{*}{ ITS1 } & LITSR & \multirow[t]{2}{*}{$300-350$} & CTGGATCATITTCCGATG & \multirow[b]{2}{*}{$\begin{array}{l}94{ }^{\circ} \mathrm{C} \text { for } \\
5 \mathrm{~min}, 94{ }^{\circ} \mathrm{C} \\
\text { for } 30 \mathrm{~s}, 53{ }^{\circ} \mathrm{C} \\
\text { for } 30 \mathrm{~s}, 72^{\circ} \mathrm{C} \\
\text { for } 30 \mathrm{~s}, 72^{\circ} \mathrm{C} \\
\text { for } 5 \mathrm{~min} \\
\text { (30 cycles) }\end{array}$} & \multirow[t]{2}{*}{30.6} & \multirow[t]{2}{*}{5.0} & \multirow[t]{2}{*}{1.0} & \multirow[t]{2}{*}{1.0 (15 pmol) } & \multirow[t]{2}{*}{$1.4(1 \mathrm{U} / \mu \mathrm{l})$} & \multirow[t]{2}{*}{10} & \multirow[t]{2}{*}{50} \\
\hline & L5.8S & & TGATACCACTTATCGCACTT & & & & & & & & \\
\hline & SAC & \multirow[t]{2}{*}{$280-330$} & CATTTCCGATGATTACACC & \multirow{2}{*}{$\begin{array}{l}94{ }^{\circ} \mathrm{C} \text { for } \\
5 \text { min, } 94{ }^{\circ} \mathrm{C} \\
\text { for } 30 \mathrm{~s}, 57^{\circ} \mathrm{C} \\
\text { for } 30 \mathrm{~s}, 72^{\circ} \mathrm{C} \\
\text { for } 30 \mathrm{~s}, 72^{\circ} \mathrm{C} \\
\text { for } 5 \text { min } \\
\text { (30 cycles) }\end{array}$} & \multirow[t]{2}{*}{10.6} & \multirow[t]{2}{*}{2.5} & \multirow[t]{2}{*}{0.5} & \multirow[t]{2}{*}{0.5 (7.5 pmol) } & \multirow[t]{2}{*}{$0.7(0.5 \mathrm{U} / \mu \mathrm{l})$} & \multirow[t]{2}{*}{$10^{\mathrm{b}}$} & \multirow[t]{2}{*}{25} \\
\hline & VAN2 & & CGTTCTTCAACGAAATAGG & & & & & & & & \\
\hline
\end{tabular}

asterile distilled water

${ }^{b} 10 \mu l$ of a $1 / 40$ dilution of the first PCR amplicons

Mus spretus (7.11\%), 11 Meriones shawi (5.58\%), 9 Rattus norvegicus (4.57\%), 6 Meriones libycus (3.05\%), 4 Mastomys erythroleucus (2.03\%), 4 Gerbillus campestris (2.03\%) and 2 Lemniscomys barbarus (1.01\%).

Leishmania species was detected in 18 specimens (Table 3): $6 \mathrm{R}$. rattus (out of 80 captured; 7.5\%), $11 \mathrm{M}$. musculus (out of 50 captured; 22\%), and one $R$. norvegicus (out of 9 captured; $11.11 \%$ ). Statistical analysis, using Chi-square test of independence, of infestation rate

Table 2 Rodent species captured in the study area

\begin{tabular}{lllll}
\hline Species & Male & Female & Total & $\%$ \\
\hline Rattus rattus & 28 & 52 & 80 & 40.61 \\
Mus musculus & 14 & 36 & 50 & 25.38 \\
Apodemus sylvaticus & 6 & 11 & 17 & 8.63 \\
Mus spretus & 6 & 8 & 14 & 7.11 \\
Meriones shawi & 5 & 6 & 11 & 5.58 \\
Rattus norvegicus & 4 & 5 & 9 & 4.57 \\
Meriones libycus & 1 & 5 & 6 & 3.05 \\
Mastomys erythroleucus & 1 & 3 & 4 & 2.03 \\
Gerbillus campestris & 2 & 2 & 4 & 2.03 \\
Lemniscomys barbarus & 0 & 2 & 2 & 1.01 \\
Total & 67 & 130 & 197 & 100 \\
\hline
\end{tabular}

according to rodent species showed no significant correlation $\left(\chi^{2}=5.768, d f=2, P=0.056\right)$.

Leishmania infantum DNA was detected in the different organs of 16 (8.12\%) specimens (Table 3): in the liver $(18.75 \%)$ and the spleen $(18.75 \%)$ of three specimens $(n=3)$, and in the skin $(81.25 \%)$ of 13 specimens ( $n=13)$. Leishmania tropica DNA was found only in the skin of 2 (1\%) specimens (Additional file 1: Figures S1-S3).

According to the region, Leishmania spp. DNA was detected in 3 of the 4 investigated regions: Al Haouz, Chichaoua and Essaouira (Table 4); with a very significant difference $\left(\chi^{2}=20.116, d f=3, P<0.0001\right)$. Leishmania infantum was detected in the Al Haouz region in $14.28 \%(3 / 21)$ of $R$. rattus, and in $46.15 \%(6 / 13)$ of $M$. musculus and L. tropica was identified in Chichaoua region in $14.28 \%(1 / 7)$ of $M$. musculus.

Both Leishmania species were detected in Essaouira region: L. infantum was identified in $17.64 \%$ (3/17) of $R$. rattus, in $33.33 \%(1 / 3)$ of $R$. norvegicus, and in $27.27 \%$ (3/11) of M. musculus; while, L. tropica was identified in 9.10\% (1/11) of M. musculus. In Marrakesh region, no Leishmania spp. DNA was detected in any of the 55 animals captured (Table 4).

Ten animals showed ear lobe skin lesions (Fig. 2), of which $50 \%$ were confirmed positive for L. infantum. 
Table 3 Molecular identification of Leishmania species from rodent species by tissue/organ

\begin{tabular}{|c|c|c|c|c|c|c|c|c|c|c|}
\hline \multirow{2}{*}{$\begin{array}{l}\text { Rodent species and } \\
\text { number of specimens }\end{array}$} & \multicolumn{4}{|c|}{$\operatorname{LnPCR}$} & \multicolumn{4}{|c|}{ ITS1-PCR } & \multirow{2}{*}{$\begin{array}{l}\text { Leishmania } \\
\text { spp. }\end{array}$} & \multirow[t]{2}{*}{ Identity (\%) } \\
\hline & L & $\mathrm{Sp}$ & $\mathrm{S}$ & $\overline{\mathrm{Sl}}$ & $\bar{L}$ & $S p$ & $S$ & $\overline{S l}$ & & \\
\hline R. norvegicus $(n=1 / 9)$ & $P$ & $P$ & $\mathrm{~N}$ & - & $P$ & $P$ & $\mathrm{~N}$ & - & L. infantum & 99 \\
\hline \multirow[t]{6}{*}{ R. rattus $(n=6 / 80)$} & $P$ & $P$ & $\mathrm{~N}$ & - & $P$ & $P$ & N & - & L. infantum & 99 \\
\hline & $P$ & $P$ & N & - & $P$ & $P$ & N & - & L. infantum & 99 \\
\hline & N & N & $P$ & $P$ & N & $N$ & $P$ & $P$ & L. infantum & 99 \\
\hline & N & $\mathrm{N}$ & $P$ & $P$ & $\mathrm{~N}$ & $N$ & $P$ & $P$ & L. infantum & 99 \\
\hline & N & $\mathrm{N}$ & $P$ & - & N & $N$ & $P$ & - & L. infantum & 98 \\
\hline & N & $\mathrm{N}$ & $P$ & - & $\mathrm{N}$ & $N$ & $P$ & - & L. infantum & 99 \\
\hline \multirow[t]{9}{*}{ M. musculus $(n=9 / 50)$} & N & N & $P$ & - & N & N & $P$ & - & L. infantum & 98 \\
\hline & N & N & P & - & N & N & $\mathrm{P}$ & - & L. infantum & 99 \\
\hline & N & N & $P$ & - & N & N & $\mathrm{P}$ & - & L. infantum & 98 \\
\hline & N & $\mathrm{N}$ & $P$ & - & $\mathrm{N}$ & $N$ & $P$ & - & L. infantum & 99 \\
\hline & N & N & $P$ & - & N & N & $P$ & - & L. infantum & 99 \\
\hline & N & N & $\mathrm{P}$ & - & N & $N$ & $P$ & - & L. infantum & 100 \\
\hline & N & $\mathrm{N}$ & $P$ & $P$ & $\mathrm{~N}$ & N & $P$ & $P$ & L. infantum & 99 \\
\hline & N & N & $P$ & $\mathrm{P}$ & N & N & $P$ & $P$ & L. infantum & 99 \\
\hline & N & $\mathrm{N}$ & P & $P$ & $\mathrm{~N}$ & $N$ & $P$ & P & L. infantum & 99 \\
\hline \multirow[t]{2}{*}{ M. musculus $(n=2 / 50)$} & N & N & $P$ & - & N & N & $\mathrm{P}$ & - & L. tropica & 96 \\
\hline & $\mathrm{N}$ & $\mathrm{N}$ & $P$ & - & $\mathrm{N}$ & $N$ & $P$ & - & L. tropica & 97 \\
\hline
\end{tabular}

Abbreviations: L Liver, S Skin, SI Skin lesion, Sp Spleen, $N$ Negative, $P$ Positive, - , absence of skin lesion

Three of these positive animals showed, in addition, splenomegaly and hepatomegaly (compatible with visceral leishmaniasis).

\section{Discussion}

The identification of the natural hosts of Leishmania species is essential to understand the epidemiology of the disease. To our knowledge, there have been no data published since 1982 on natural Leishmania infection in rodent species in Morocco [19].

In the present study, L. infantum DNA was detected in six $R$. rattus, nine $M$. musculus (both anthropophilic species) and one $R$. norvegicus, while $L$. tropica DNA was detected in two M. musculus. This is the first time that $L$. infantum and $L$. tropica infections have been detected in rodent species in Morocco. In the wider Mediterranean region, $L$. infantum (which causes visceral and cutaneous zoonotic leishmaniasis) has been identified in naturally infected wild rodents including $R$. rattus, $R$. norvegicus and M. musculus [8, 10, 12, 15, 16, 33-35]. In Morocco, dogs make up the main host reservoir for $L$. infantum $[17,36]$. However, on the Island of Montecristo (Italy), where no dogs are present, up to $15.5 \%$ of $R$. rattus individuals have been reported infected with $L$. infantum [37], maintaining a sylvatic transmission cycle.

Leishmania tropica-induced cutaneous leishmaniasis is commonly considered an anthroponotic disease that does not involve an animal reservoir [38], but zoonotic transmission has been demonstrated in Jordan, Palestine and Israel [39, 40].

In north Africa, several rodent species have been implicated in the transmission of L. tropica [39-42]:

Table 4 Rodent species infected with Leishmania species by region

\begin{tabular}{|c|c|c|c|c|c|c|c|c|}
\hline & \multicolumn{2}{|c|}{ El Haouz } & \multicolumn{2}{|c|}{ Chichaoua } & \multicolumn{2}{|c|}{ Essaouira } & \multicolumn{2}{|c|}{ Marrakesh } \\
\hline & Neg & Pos & $\mathrm{Neg}$ & Pos & $\mathrm{Neg}$ & Pos & $\mathrm{Neg}$ & Pos \\
\hline R. rattus & 18 & $\begin{array}{l}3 \text { L. infantum } \\
(14.28 \%)\end{array}$ & 12 & 0 & 14 & $\begin{array}{l}\text { 3 L. infantum } \\
(17.64 \%)\end{array}$ & 30 & 0 \\
\hline M. musculus & 7 & $\begin{array}{l}6 \text { L. infantum } \\
(46.15 \%)\end{array}$ & 6 & $\begin{array}{l}1 \text { L. tropica } \\
(14.28 \%)\end{array}$ & 7 & $\begin{array}{l}3 \text { L. infantum } \\
(27.27 \%)+1 \\
\text { L. tropica }(9.10 \%)\end{array}$ & 19 & 0 \\
\hline R. norvegicus & 0 & 0 & 0 & 0 & 2 & $\begin{array}{l}1 \text { L .infantum } \\
(33.33 \%)\end{array}$ & 6 & 0 \\
\hline
\end{tabular}


Ctenodactylus gundi has been proposed as a reservoir host in Tunisia [42, 43], while in Algeria, human cutaneous leishmaniasis caused by Leishmania killicki (a variant of $L$. tropica) is considered a zoonotic form with $P$. sergenti as a vector and Massoutiera mzabi as a reservoir [39]. However, in Morocco L. tropicais generally considered an anthroponotic species, despite its identification in dogs on many occasions [44-46].

In the present study, the regions of Chichaoua, $\mathrm{Al}$ Haouz and Essaouira were known to be endemic foci of L. tropica-induced cutaneous leishmaniasis for humans [47-49], while, L. infantum is reported responsible for sporadic human cases of visceral leishmaniasis in these areas $[50,51]$. In the same study area, Boussaa et al. [23] reported $L$. infantum-induced leishmaniasis in dogs, which returned very high seroprevalence results $(81.8$ and $87.8 \%$ as determined by ELISA and Western blotting, respectively).

In addition, the vector sand flies Phlebotomus perniciosus and $P$. sergenti have been found engorged with rodent blood in southern Portugal [52] but also in central Morocco [53] where the sand fly composition is well established [54]. Svobodovà et al. [55] reported the transmission of L. tropica to mice by the bite of Phlebotomus sergenti, a species widespread in our study area [54].

The richness of rodent species $(n=10)$ across the present study area is favoured by ecological factors. Prevalence and abundance of rodent species areknown to be associated with abundant vegetation [56]. In arid and semi-arid regions, such in the study area, many authors suggested trophic cascade including precipitations, vegetation and rodent density 1 year later $[57,58]$.

\section{Conclusion}

To the best of our knowledge, molecular detection of $L$. infantum DNA in M. musculus, $R$. norvegicus and $R$. rattusand of $L$. tropica DNA in $M$. musculus is reported here for the first time in Morocco. These results suggest the possible involvement of rodent species in L. tropica and $L$. infantum cycles. The present findings should be taken into consideration when developing programs to combat this disease in Morocco.

\section{Additional file}

Additional file 1: Figure S1. Profile of agarose (1.5\%) gel for diagnostic of Leishmania spp. in DNA extracted from tissue from rodent species, using $L n P C R$ for to amplify part of the SSU rRNA gene for diagnosis. Lane MM: 100 bp molecular marker (DNA ladder); Lanes 1, 12: negative controls (no DNA PCR); Lane 13: positive control (MHOM/FR/78/LEM75): Lanes 2-11: DNA extracted of tissue from rodent species. LnPCR for first amplification was carried out using R221/R332 primers. Figure S2. Profile of agarose (1.5\%) gel for diagnostic of Leishmania spp. in DNA extracted from tissue from rodent species, using LnPCR for to amplify part of the SSU rRNA gene for diagnosis. Lane MM: 100 bp molecular marker (DNA ladder); Lanes 1, 12, 14: negative controls (no DNA PCR); Lanes 13, 15: positive controls (MHOM/FR/78/LEM75); Lanes 2-11: DNA extracted of tissue from rodent species. LnPCR for second amplification was carried out using R233/R333 primers. Figure S3. Profile of agarose (1.5\%) gel for characterization of Leishmania species in DNA extracted from tissue from rodent species, using ITS1-PCR for to amplify the ribosomal internal transcribed spacer 1 (ITS1) region. Lane MM: 100 bp molecular marker (DNA ladder); Lanes 1, 16, 18: negative controls (no DNA PCR); Lanes 17, 19: positive controls (MHOM/FR/78/LEM75); Lanes 2-15: DNA extracted of tissue from rodent species. ITS1-PCR for second amplification was carried out using SACNAN2 primers. (DOCX $314 \mathrm{~kb}$ )

\section{Abbreviations}

ELISA: Enzyme-linked immunosorbent assay; ITS1: Internal transcribed spacer 1; LnPCR: Leishmania nested polymerase chain reaction; MM: Molecular marker; MON: Leishmania major Montpellier; SSU rRNA: Small subunit ribosomal ribonucleic acid; Tth: Thermus thermophilus; WHO: World Health Organization

\section{Acknowledgements}

The authors would like to thank the staff members of the Laboratory of Ecology and Environment, Faculty of Sciences, Semlalia, Cadi Ayyad University, Morocco and Parasitology Service of National Center of Microbiology, Institute of Health Carlos III, Majadahonda, Madrid, Spain; for hosting and supporting the study.

\section{Funding}

Not applicable.

\section{Availability of data and materials}

The data supporting the conclusions of this article are provided within the article. Representative sequences were submitted to the GenBank database under the accession numbers: L. infantum ex M. musculus (MF977313), ex R. norvegicus (MF977315), ex R. rattus (MF977314); L. tropica ex M. musculus (MF977312)

\section{Authors' contributions}

$\mathrm{ME}, \mathrm{SB}$ and $\mathrm{AB}$ conceived the project, and were involved in capturing and rodent identification, conducting literature searches and analysis of the results, and participated in the writing of the manuscript. ME, CC, JN, EC, OS and JM were involved in the molecular diagnostics (DNA extraction and PCR) of Leishmania. All authors read and approved the final manuscript.

Ethics approval and consent to participate

All animals were treated according to European decree NOR: AGRG1238767A (1st February 2013) regarding the ethical evaluation and authorization of projects involving animals for experimental procedures. All efforts were made to minimize the suffering of the animals used.

\section{Consent for publication}

Not applicable.

\section{Competing interests}

The authors declare that they have no competing interests.

\section{Publisher's Note}

Springer Nature remains neutral with regard to jurisdictional claims in published maps and institutional affiliations.

\section{Author details}

${ }^{1}$ Ecology and the Environment Laboratory L2E, (URAC 32, CNRST ERACNERS 06), Faculty of Sciences Semlalia, Cadi Ayyad University, Marrakesh, Morocco. ${ }^{2} \mathrm{WHO}$ Collaborating Centre for Leishmaniasis, Parasitology Service, National Center of Microbiology Institute of Health Carlos III, Majadahonda, Madrid, Spain. ${ }^{3}$ ISPITS-Higher Institute of Nursing and Technical Health Occupations, Ministry of Health, Marrakesh, Morocco. 


\section{Received: 26 January 2017 Accepted: 21 September 2017}

Published online: 02 October 2017

\section{References}

1. Lainson R, Shaw JJ. Evolution, classification and geographical distribution. In: Peters W, Killick-Kendrick R, editors. The Leishmaniasis in Biology and Medicine. London: Academic Press; 1987.

2. Pesson B, Ready JS, Benabdennbi I, Martin-Sanchez J, Esseghir S, Cadi Soussi $\mathrm{M}$, et al. Sand flies of the Phlebotomus perniciosus complex: mitochondrial introgression and a new sibling species of $P$. longicuspis in the Moroccan Rif. Med Vet Entomol. 2004;18:25-37.

3. Gramiccia M, Gradoni L. The current status of zoonotic leishmaniases and approaches to disease control. Int J Parasitol. 2005;35(11-12):1169-80.

4. Ashford RW. Leishmaniasis reservoirs and their significance in control. Clin Dermatol. 1996;14:523-32.

5. Quinnell RJ, Courtenay O. Transmission, reservoir hosts and control of zoonotic visceral leishmaniasis. Parasitology. 2009;136(14):1915-34.

6. Kahime K, Boussaa S, Bounoua L, Ouanaimi F, Messouli M, Boumezzough A. Leishmaniasis in Morocco: diseases and vectors. Asian Pac J Trop Dis. 2014:4(2):S530-4.

7. El-Adhami B. Isolation of Leishmania from a black rat in the Baghdad area. Iraq Am J Trop Med Hyg. 1976;25:759-61.

8. Pozio E, Gradoni L, Bettini SE, Gramiccia M. Leishmaniasis in Tuscany (Italy) $V$. Further isolation of Leishmania from Rattus rattus in the Province of Grosseto. Ann Trop Med Parasitol. 1981;75:393-5.

9. Gradoni L, Pozio E, Gramiccia M, Maroli M, Bettini S. Leishmaniasis in Tuscany (Italy): VII. Studies on the role of the black rat, Rattus rattus, in the epidemiology of visceral leishmaniasis. Trans R Soc Trop Med Hyg. 1983;77(4):427-31.

10. Giannini SH. Infection and detection of Leishmania infections in Rattus norvegicus. Trans R Trop Med Hyg. 1985;79:458-61.

11. Morillas-Márquez F, Benavides-Delgado I, González-Castro J, Reyes Agaña A, Valero-López A. Ocurrence of Leishmania spp. in Rattus rattus in the province of Granada. Ann Parasitol Hum Comp. 1985;60:768-70.

12. Ibrahim EA, Al-Zahrani MA, Al-Tuwaigri AS, Al-Shammary FJE, Evans DA Leishmania infecting man and wild animals in Saudi Arabia. The black rat (Rattus rattus) a probable reservoir of visceral leishmaniasis in Gizan province, south-west Saudi Arabia. Trans R Soc Trop Med Hyg. 1992;86:513-4.

13. Di Bella C, Vitale F, Russo G, Greco A, Milazzo C, Aloise G, Cagnin M. Are rodents a potential reservoir for Leishmania infantum in Italy? J Mt Ecol. 2003;7:125-9.

14. Mohebali M, Javadian $E$, Yaghoobi-Ershadi MR, Akhavan AA, Hajjaran $H$, Abaei MR. Characterization of Leishmania infection in rodents from endemic areas of the Islamic Republic of Iran. East Mediterr Health J. 2004;10(4-5):591-9.

15. Motazedian MH, Parhizkari M, Mehrabani D, Hatam G, Asgari Q. First detection of Leishmania major in Rattus norvegicus from Fars Province. Southern Iran Vector Borne Zoonotic Dis. 2010;10(10):96975.

16. Papadogiannakis E, Spanakos G, Kontos V, Menounos PG, Tegos N, Vakalis N. Molecular detection of Leishmania infantum in wild rodents (Rattus norvegicus) in Greece. Zoonoses Public Health. 2010;57(7-8):e23-5.

17. Helhazar M, Leitao J, Duarte A, Tavares L, Pereira da Fonseca I. Natural infection of synathropic rodent species Mus musculus and Rattus norvegicus by Leishmania infantum in Sesimbra and Sintra Portugal. Parasit Vectors. 2013;6:88

18. Rioux JA, Petter F, Zahaf A, Lanotte G, Houin R, Jarry D, et al. [Isolation of Leishmania major Yakimoff and Shokhor. 1914 (KinetoplastidaTrypanosomatidae) in Meriones shawi-shawi (Duvernoy. 1842) (RodentiaGerbillidae) in Tunisia]. Ann Parasitol Hum Comp. 1986:61(2):139-45 (In French).

19. Rioux JA, Petter F, Akalay O, Lanotte G, Ouazani A, Seguignes M, Mohcine A. Meriones shawi (Duvernoy,1842) (Rodentia, Gerbillidae), reservoir of Leishmania major, Yakimoff \& Schokhor, 1914 in South Morocco. C R Seances Acad Sci III. 1982;294(11):515-7.

20. Echchakery M, Boussaa S, Kahime K, Boumezzough A. Epidemiological role of a rodent in Morocco: case of cutaneous leishmaniasis. Asian Pac J Trop Dis. 2015;5(8):589-94

21. World Health Organization (WHO) Control of the Leishmaniasis. Report of a Meeting of the WHO Expert Committee on the Control of Leishmaniases. World Health Organization Technical Report Series No 949. Geneva: WHO; 2010.
22. Silva ES, Gontijo CM, Melo MN. Contribution of molecular techniques to the epidemiology of Neotropical Leishmania species. Trends Parasitol. 2005;21(12):550-2

23. Boussaa S, Kasbari M, El Mzabi A, Boumezzough A. Epidemiological investigation of canine leishmaniasis in southern Morocco. Adv Epidemiol. 2014:2014:104697.

24. Aulagnier S, Thévenot M. Catalogue of wild mammals in Morocco. Trav Inst Sci Rabat Sér Zool. 1986:41:1-163. (In French)

25. Van Eys GJ, Schoone GJ, Kroon NC, Ebeling SB. Sequence analysis of small subunit ribosomal RNA genes and its use for detection and identification of Leishmania parasites. Mol Biochem Parasitol. 1992;51:133-42.

26. Meredith SEO, Zijlstra EE, Schoone GJ, Kroon CCM, Van Eys GJJM, Schaeffer $\mathrm{KU}$, et al. Development and application of the polymerase chain reaction for the detection and identification of Leishmania parasites in clinical material. Arch Inst Pasteur Tunis. 1993:70:419-31.

27. Cruz I, Cañavate C, Rubio JM, Morales MA, Chicharro C, Laguna F, et al. A nested polymerase chain reaction (Ln-PCR) for diagnosing and monitoring Leishmania infantum infection in coinfected patients with human immunodeficiency virus. Trans R Soc Trop Med Hyg. 2002:96:185-9.

28. El Tai NO, Osman OF, El Fari M, Presber W, Schönian G. Genetic heterogeneity of ribosomal internal transcribed spacer (ITS) in clinical samples of Leishmania donovani spotted on filter paper as revealed by single-strand conformation polymorphisms (sscp) and sequencing. Trans Royal Soc Trop Med Hyg. 2000;94:1-5

29. Schonian G, Nasereddin A, Dinse N, Schweynoch C, Schallig HD, Presber W, Jaffe CL. PCR diagnosis and characterization of Leishmania in local and imported clinical samples. Diagn Microbiol Infect Dis. 2003;47:349-58.

30. Cruz I, Millet A, Carrillo E, Chenik M, Salotra P, Verma S, et al. An approach for interlaboratory comparison of conventional and real-time PCR assays for diagnosis of human leishmaniasis. Exp Parasitol. 2013;134:281-9.

31. Van der Auwera G, Bart A, Chicharro C, Cortes S, Davidsson L, Di Muccio T, et al. Comparison of Leishmania typing results obtained from 16 European clinical laboratories in 2014. EuroSurveill. 2016;21(49):30418.

32. Hall TA. Bio Edit: A user-friendly biological sequence alignment editor and analysis program for Windows 95/98/NT. Nucleic Acids Symp Ser. 1999:41:95-8.

33. Portús M, Gállego M, Riera C, Aisa MJ, Fisa R, Castillejo S. Wild and domestic mammals in the life cycle of Leishmania infantum in Southwest Europe. A literature review and studies performed in Catalonia (Spain). Rev Iber Parasitol. 2002:62:72-6.

34. Millán J, Ferroglio E, Solano-Gallego L. Role of wildlife in the epidemiology of infection in Europe. Parasitol Res 2014;113(6):2005-2014.

35. Navea-Pérez HM, Díaz-Sáez V, Corpas-López V, Merino-Espinosa G, MorillasMárquez F, Martín-Sánchez J. Leishmania infantum in wild rodents: reservoirs or just irrelevant incidental hosts? Parasitol Res. 2015;114(6):2363-70.

36. Rhajaoui M. Human leishmaniases in Morocco: a nosogeographical diversity. Pathol Biol. 2011:59(4):226-9. (In French)

37. Zanet S, Sposimo P, Trisciuoglio A, Giannini F, Strumia F, Ferroglio E. Epidemiology of Leishmania infantum, Toxoplasma gondii and Neospora caninum in Rattus rattus in absence of domestic reservoir and definitive hosts. Vet Parasitol. 2014:199(3-4):247-9.

38. Ashford RW. The leishmaniases as emerging and reemerging zoonoses. Int J Parasitol. 2000:30:1269-81.

39. Jacobson RL, Eisenberger CL, Svobodova M, Baneth G, Sztern J, Carvalho J, et al. Outbreak of cutaneous leishmaniasis in northern Israel. J Infect Dis. 2003;188:1065-73.

40. Talmi-Frank D, Jaffe CL, Nasereddin A, Warburg A, King R, Svobodova M, et al. Leishmania tropica in rock hyraxes (Procavia capensis) in a focus of human cutaneous leishmaniasis. Am J Trop Med Hyg. 2010;82:814-8.

41. Boubidi SC, Benallal K, Boudrissa A, Bouiba L, Bouchareb B, Garni R, et al. Phlebotomus sergenti (Parrot, 1917) identified as Leishmania killicki host in Ghardaia, south Algeria. Microbes Infect. 2011;13(7):691-6.

42. Bousslimi N, Ben-Ayed S, Ben-Abda I, Aoun K, Bouratbine A. Natural infection of north African gundi (Ctenodactylus gundi) by Leishmania tropica in the focus of cutaneous leishmaniasis, Southeast Tunisia. Am J Trop Med Hyg. 2012:86(6):962-5.

43. Jaouadi K, Haouas N, Chaara D, Gorcii M, Chargui N, Augot D, et al First detection of Leishmania killicki (Kinetoplastida, Trypanosomatidae) in Ctenodactylus gundi (Rodentia, Ctenodactylidae), a possible reservoir of human cutaneous leishmaniasis in Tunisia. Parasit Vectors. 2011;4:159. 
44. Dereure J, Rioux JA, Gallego M, Perieres J, Pratlong F, Mahjour J, Saddiki H. Leishmania tropica in Morocco: infection in dogs. Trans R Soc Trop Med Hyg. 1991;85(5):595.

45. Guessous-Idrissi N, Riyad M, Chiheb S, Hamdam A, Hamdam S, Krimech A. La leishmaniose cutanée à Taza. Les Cahiers du Médecin. 1999;2:37-40.

46. Lemrani M, Nejjar R, Pratlong F. A new Leishmania tropica zymodemecausative agent of canine visceral leishmaniasis in northern Morocco. Ann Trop Med Parasitol. 2002;96:637-8.

47. Guernaoui S, Boumezzough A, Pesson B, Pichon G. Entomological investigations in Chichaoua: an emerging epidemic focus of cutaneous leishmaniasis in Morocco. J Med Entomol. 2005:42:697-701.

48. Boussaa S, Pesson B, Boumezzough A. Faunistic study of the sand flies (Diptera: Psychodidae) in an emerging focus of cutaneous leishmaniasis in Al Haouz Province, Morocco. Ann Trop Med Parasitol. 2009;103:73-83.

49. Ajaoud M, Es-sette N, Hamdi S, El-ldrissi AL, Riyad M, Lemrani M. Detection and molecular typing of Leishmania tropica from Phlebotomus sergenti and lesions of cutaneous leishmaniasis in an emerging focus of Morocco. Parasit Vectors. 2013;6:217.

50. Kahime K, Boussaa S, Ouanaimi F, Boumezzough A. Species composition of phlebotomine sand fly fauna in an area with sporadic cases of Leishmania infantum human visceral leishmaniasis, Morocco. Acta Trop. 2015;148:58-65.

51. Moroccan Ministry of Health. A report on progress of control programs against parasitic diseases. Directorate of Epidemiology and Disease Control, Ministry of Health, Rabat, Morocco; 2014.

52. Maia C, Dionísio L, Afonso MO, Neto L, Cristóvão JM, Campino L. Leishmania infection and host-blood feeding preferences of phlebotomine sand flies and canine leishmaniasis in an endemic European area, the Algarve Region in Portugal. Mem Inst Oswaldo Cruz Rio de Janeiro. 2013;108(4):481-7.

53. Ajaoud M, Es-Sette N, Charrel RN, Laamrani-Idrissi A, Nhammi H, Riyad M. Phlebotomus sergenti in a cutaneous leishmaniasis focus in Azilal Province (High Atlas, Morocco): Molecular detection and genotyping of Leishmania tropica, and feeding behavior. PLoS Negl Trop Dis. 2015;9(3):e0003687.

54. Boussaa S, Kahime KM, Samy A, Ben Salem A, Boumezzough A. Species composition of sand flies and bionomics of Phlebotomus papatasi and P. sergenti (Diptera: Psychodidae) in cutaneous leishmaniasis endemic foci, Morocco. Parasit Vectors. 2016;9:60.

55. Svobodovà M, Votypka J, Nicolas L, Volf P. Leishmania tropica in the black rat (Rattus rattus): persistence and transmission from asymptomatic host to sand fly vector Phlebotomus sergenti. Microbes Infect. 2003:5:361-4.

56. Aoun K, Bouratbine A. Cutaneous leishmaniasis in North Africa: a review. Parasite. 2014:21:14

57. Yates TL, Mills JN, Parmenter CA, Ksiazek TG, Parmenter RR, Vande Castle JR, et al. The ecology and evolutionary history of an emergent disease: Hantavirus pulmonary syndrome. Bioscience. 2002;52:989-98.

58. Bounoua L, Kahime K, Houti L, Blakey T, Ebi KL, Zhang P, et al. Linking climate to incidence of zoonotic cutaneous leishmaniasis (L. major) in preSaharan North Africa. Int J Environ Res Public Health. 2013;10(8):3172-91.

\section{Submit your next manuscript to BioMed Central and we will help you at every step:}

- We accept pre-submission inquiries

- Our selector tool helps you to find the most relevant journal

- We provide round the clock customer support

- Convenient online submission

- Thorough peer review

- Inclusion in PubMed and all major indexing services

- Maximum visibility for your research

Submit your manuscript at www.biomedcentral.com/submit 